\title{
The development of learning modul of colloid system integrated with project based learning (PjBL) system to increase the result of students' learning
}

\author{
Sri Wartika, ${ }^{1, *}$, Zainuddin Muchtar ${ }^{2}$ and Wesly Hutabarat ${ }^{2}$ \\ ${ }^{1}$ Chemistry Education Study Program, Postgraduate Universitas Negeri Medan, Medan 20221, \\ Indonesia \\ ${ }^{2}$ Department of Chemistry, Universitas Negeri Medan, Medan 20221, Indonesia \\ *Corresponding author: SW, sriwartika.pascakimia16@gmail.com
}

DOI: $10.24114 / j p k i m . v 13 i 1.24147$

Article history:

Received: 08 January 2021

Revised: 29 March 2021

Accepted: 29 March 2021

\begin{abstract}
This research aims to develop learning material in the form of colloid learning system module integrated with PjBL model in accordance with curriculum 2013 and to find out the increasing of students learning result after using learning module of colloid system integrated with Project Based Learning (PjBL) system. The type of the study is development research and experiment. It examines how the module of Integrated with Project Based Learning ( $\mathrm{PjBL}$ ) integrated with PjBL model is organized based on curriculum 2013 and the experiment is managed by analyzing the using of the module in senior high school. The study was carried out to the students of $9^{\text {th }}$ grade of SMA Negeri 1 Sunggal and SMA Swasta Muhammadiyah 18 Sunggal school year of 2018/2019 in second semester. The data are examined by using independent sample of T-test by using SPSS 23 program. The result shows that colloid system module integrated with PjBL developed model is valid and appropriate to be used based on BSNP.The score of the students who are taught by with the module has increased in average about 82.80 (high) with a pretest score of 31.80 (low), the score of the students who are taught by using textbooks increase to 77.60 (middle) with a pretest score of 32.40 (low).
\end{abstract}

Keywords: Module, Colloid, Project based learning

\section{Introduction}

Learning material is one of the main factors in the learning process. The teachers can explain the material clearly, at the same time it will be incomplete when there is no learning material. The learning material is still the main priority (Adha et al. 2016). Learning material is one of the knowledge resources which is very useful for students and it becomes one of the main factors to the students' achievement. Students will 
have big obstacle to discover and develop the potentials in them. The learning material should refer to the updated curriculum. The 2013 curriculum uses scientific approach in learning process to build knowledge, skill and attitude (Silaban, 2017).

A module is the learning material which are arranged and presented in written to help the users to learn by themselves (Daryanto, 2013; Silaban, 2021). A modul is also a set of material which consists of the aim of the learning which helps students to obtain the competence that they need and to measure the learning result in order to achieve the learning goals (Muchtar et al. 2019; Nuraini et al. 2019).

Project based learning ( $P j B L$ ) is an innovative learning model which focuses on contextual learning through a set of complex activities. Project based learning involves the students to solve series of problems and meaningful project. It gives the students some opportunities to work and to construct their learning process independently and to make their own meaningful and realistic product (Okudan \& Rzasa, 2004). According to Manalu et al. (2016) and Nasution et al. (2018), generally the students' ability to think creatively in project based learning is better than the students with conventional method in colloid system. It is in line with the research by (Novita et al. 2016; Lukman et al. 2019) who concludes that the learning with project based learning model in learning colloid system topic is able to increase the quality of the learning process and result.

\section{Methods}

\subsection{Sample}

The research samples are decided by using purposive sampling technique. The samples in this research are (1) students' textbook; (2) Students of $9^{\text {th }}$ grade from two schools, SMA Negeri 1 Sunggal and SMA Swasta Muhammadiyah 18 Sunggal with total amount 60 students; (3) three lecturers as the module validator.

\subsection{Research Design}

The assessment is held to the experiment group which uses the colloid system module integrated with PjBL model and the control group uses student textbook. The research design by using experiment class and control class is on Fig 1.

Instrument to measure the students result is the test which has been standardized by the expert lecture. The test is in the form of multiple choice in 20 questions. The number of questions for pretest and posttest are the same to be answered in 20 minutes.

\subsection{Data Analysis}

Colloid system learning module integrated with PjBL model is analyzed with descriptive analysis by counting the percentage score of the content, language, presentation and graphics using a formula: 


\section{Percentage $=\frac{\text { Score Obtained }}{\text { Maximum Score }} \times 100 \%$}

The criteria of average validity used is on Table 1.

Table 1

The validity criteria of learning material

\begin{tabular}{c|c|c}
\hline No & Average & Criteria \\
\hline 1 & $3.26-4.00$ & Very valid and unnecessary for revision \\
\hline 2 & $2.51-3.25$ & valid and unnecessary for revision \\
\hline 3 & $1.76-2.50$ & Less valid and needs to be revised \\
\hline 4 & $1.00-1.75$ & Invalid and needs total revision \\
\hline
\end{tabular}

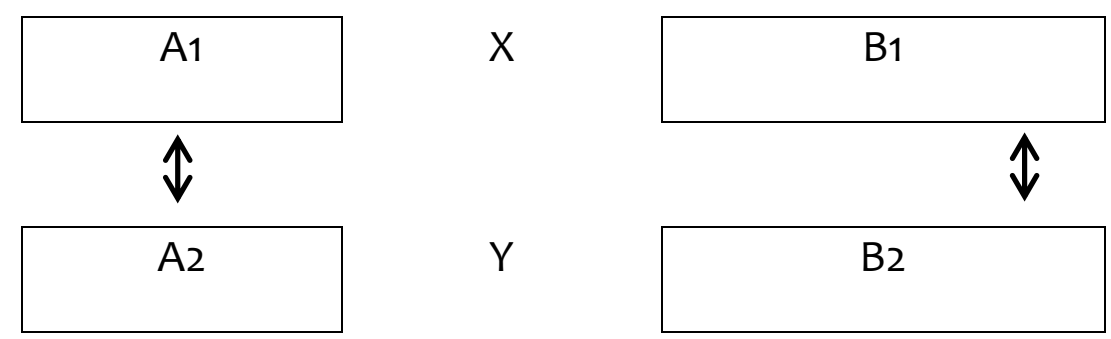

Fig 1. Research design of experiment group and control group (Sugiyono, 2017)

Explanation: A1: Pretest score of experiment group; A2: Pretest score of control group; B1: Posttest score of experiment group after being treated by using the developed module; B2: The score of control group after being treated with students textbook; $X$ : Learning process by using the developed module; and Y: Learning process by using students textbook.

The data which are obtained from the pretest and posttest score are calculated by using statistics. The technique used to analyze data in the research is the t-test technique. It uses one side assignment with the independent sample of t-test in SPSS 23.0. The criteria of the taking the decision is managed by using SPSS program for windows in significant level a 0.05 .

\section{Results and Discussion}

The research is conducted to create chemistry module in topic of colloid system integrated with the PjBL model for $11^{\text {th }}$ grade of SMA Negeri 1 Sunggal and SMA Swasta Muhammadiyah 18 Sunggal in school year 2018/2019 at the second semester.

3.1 The Appropriateness of Colloid System Module Integrated with PjBL Model

Module that has been developed in accordance with the quality standard which is determined by BSNP. The appropriateness level of the developed module based 
on BSNP covers the adequate of content, language, presentation and the adequate of graphics are shown in Fig 2.

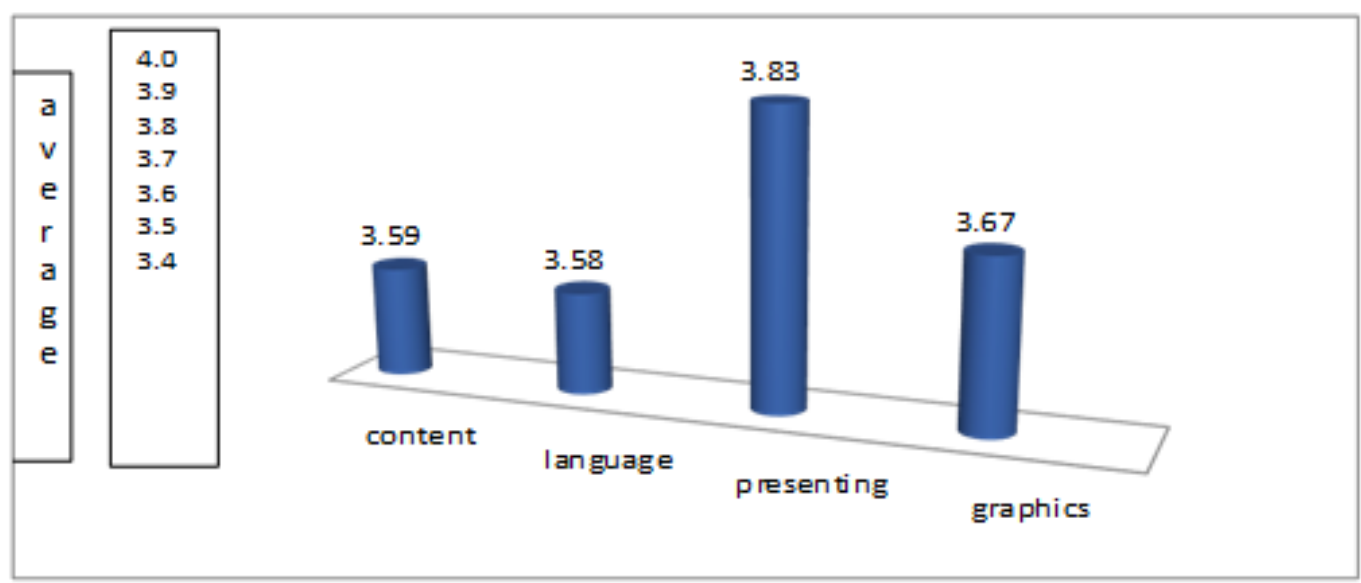

Fig 2.The graphic of the analysis result of the developed module appropriateness

The result of the colloid module which is developed based on BSNP survey in the form of percentage is: (1) Adequate test of content is 3.59 which means appropriate and unnecessary for revision; (2) Adequate test of language is 3.58 which means appropriate and unnecessary for revision; (3) Adequate test of presentation is 3.83 which means appropriate and unnecessary for revision; (4) adequate test of graphics is 3.67 which means appropriate and unnecessary for revision. The average is 3.67 which means very valid / appropriate and unnecessary for revision.

\subsection{Data description of the learning result}

Both samples answer pretest questions before they are given different treatment to find out the students' competence, before treatment teaching of the experimental group first performed a pretest (Silaban \& Simangunsong, 2015; Saragih et al. 2017). The result of the pretest score in experiment class and control class processed with SPSS 23 for windows is on Table 2. The average posttest score for experiment and control class is on Table 3. The graphic of pretest and posttest score in experiment and control is on Fig 3.

Table 2.

Pretest data from students in experiment dan control group

\begin{tabular}{l|c|c|c|c}
\hline \multicolumn{1}{c|}{ Class } & Average Score & $\begin{array}{c}\text { Deviation } \\
\text { Standard }\end{array}$ & $\begin{array}{c}\text { Highest } \\
\text { Score }\end{array}$ & $\begin{array}{c}\text { Lowest } \\
\text { Score }\end{array}$ \\
\hline Experiment & 31.80 & 9.988 & 50 & 15 \\
\hline Control & 32.40 & 9.435 & 50 & 15 \\
\hline
\end{tabular}

Learning activities using the integrated colloid system chemistry module developed by the PjBL model can be carried out independently or in group discussions, this is to provide opportunities for students to convey ideas in the 
manufacture of colloid products. This is what makes student learning outcomes using the integrated colloid system chemistry module development results higher than those taught using textbooks.

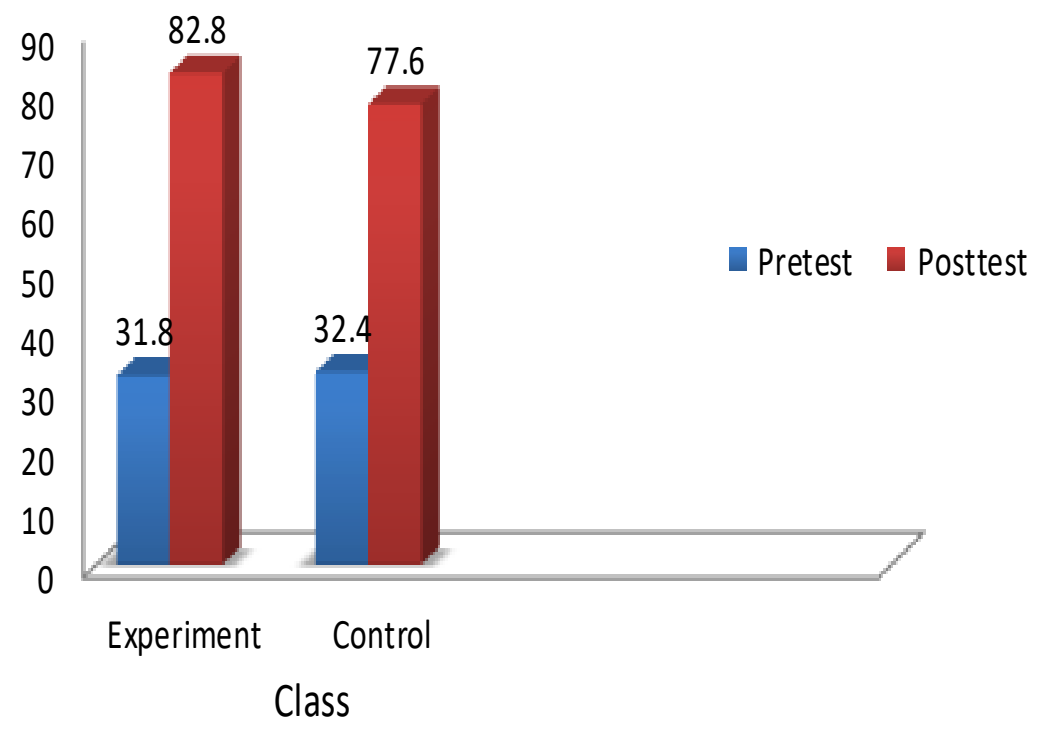

Fig 3. The graphic of pretest and posttest score in experiment and control class

The use of the developed PjBL model integrated colloid system chemistry module will open opportunities for students to learn according to their respective abilities and ways and make students develop scientific skills that are very useful in their lives. The assessment uses SPSS 23.0 for windows which is shown in Table 4.

Table 3.

Posttest data of experiment group and control group

\begin{tabular}{c|c|c|c|c}
\hline Class & Average & $\begin{array}{c}\text { Deviation } \\
\text { Standard }\end{array}$ & $\begin{array}{c}\text { Highest } \\
\text { Score }\end{array}$ & $\begin{array}{c}\text { Lowest } \\
\text { Score }\end{array}$ \\
\hline Experiment & 82.80 & 10.650 & 100 & 60 \\
\hline Control & 77.60 & 10.509 & 100 & 50 \\
\hline
\end{tabular}

Table 4

The result of increasing of students learning

\begin{tabular}{c|c|c|c|c}
\hline $\mathrm{N}$-gain score & $\operatorname{Sig}(2$-tailed) & $\alpha$ & $\mathrm{t}_{\text {count }}$ & $\mathrm{t}_{\text {table }}$ \\
\hline Equal variances assumed & 0.015 & 0.05 & 2.487 & 1.985 \\
\hline
\end{tabular}

The criteria for data assessment by using SPSS 23.0 for windows is sig. (2-tailed) < $a$ The result shows that there is different between the result of students' learning by using colloid system module integrated with PjBL model with the result of learning by using textbook. 
It is in line with the research by Novita et al. (2016) and Bahriah et al. (2017) who concludes that the learning with project based learning model in learning colloid system topic is able to to increase the quality of the learning process and result.

\section{Conclusion}

The analysis and data calculating have come to a conclusion that colloid system module integrated with PjBL developed model is very valid and appropriate to be used based on BSNP standard on 3.67 which means very valid / appropriate and unnecessary for revision. Learning result by using colloid system learning module integrated with PjBL developed model is higher compared to the result of learning by using students' textbook. The learning result by using After analyzing and calculating the data, there comes a conclusion colloid system learning module integrated with $\mathrm{PjBL}$ is in high category and the result of learning by using textbook is in middle category.

\section{Acknowledgment}

We Would like to express our gratitude to all parties who have given contribution on the research especially to the master, teacher, and student's of SMAN 1 Sunggal \& SMA Swasta Muhammadiyah 18 Sunggal.

\section{References}

Adha, N.W., Situmorang, M., \& Muchtar, Z. (2016). Pengembangan bahan ajar kimia inovatif berbasis multimedia untuk meningkatkan hasil belajar siswa pada pengajaran termokimia. Jurnal Pendidikan Kimia, 8(3), 169-177. DOI: 10.24114/jpkim.v8i3.4480

Bahriah, E. S., Suryaningsih, S., \& Yuniati, D. (2017). pembelajaran berbasis proyek pada konsep koloid untuk pengembangan keterampilan proses sains siswa. JTK (Jurnal Tadris Kimiya), 2(2), 145-152. DOI: 10.15575/jtk.v2i2.1883

Daryanto, D. (2013). Menyusun modul bahan ajar untuk persiapan guru dalam mengajar. Yogyakarta: Gava Media.

Novita, L., Eddiyanto, E., \& Situmorang, M. (2016). The development of innovative colloidal chemistry teaching module for $\mathrm{XI}$ class of senior high school based on project based learning. Jurnal Pendidikan Kimia, 8(3), 207-212. DOI: 10.24114/jpkim.v8i3.4920

Lukman, I., Damanik, M., Silaban, S., \& Kembaren, A. (2019). Development of problem based learning innovative student worksheets in learning the concept of chemistry for senior high school students. Journal of Transformative Education and Educational Leadership, 1(1), 23-28.

Manalu, E., Silaban, S., Silaban, R., \& Hutabarat, W. (2016). The development of chemical practice guidebook colloid system - based integrated contextual character values. Jurnal Pendidikan Kimia, 8(2), 87-89. DOI: 10.24114/jpkim.v8i2.4429 
Muchtar, Z., Rosalia, A.V.A., \& Silaban, S. (2019) Implementation of dubido based on contextual in improving students achievement on rate reaction. Journal of Physics: Conference Series, 1462 012053. DOI: 10.1088/1742-6596/1462/1/012053

Nasution, R., Silaban, S., \& Sudrajat, A. (2018). The influence of problem based learning, guided inquiry learning models assited by lectora inspire, and scientific attitudes to student's cognitive values. Advances in Social Science, Education and Humanities Research, 200, 265-269. DOI: 10.2991/aisteel-18.2018.58

Nuraini, N., Simorangkir, M., Silaban, S., \& Pane, E. (2019). Development of multimedia lectora inspire integrated problem based learning on carbohydrate topic for department of agrotechnology students. Advances in Social Science, Education and Humanities Research, 384, 344-348.

Okudan, G. E., \& Rzasa, S. E. (2006). A project-based approach to entrepreneurial leadership education. Technovation, 26(2), 195-210. DOI: 10.1016/j.technovation.2004.10.012

Saragih, S. H., Mahmud, M., \& Silaban, S. (2017). Development of innovative teaching material based on contextual to improve student learning outcomes of SMK on redox concept materials and compound nomenclature. IOSR Journal of Research \& Method in Education (IOSR-JRME), 7(4), 18-22.

Silaban, S., \& Simangunsong, N.S.D. (2015). Pengaruh model pembelajaran contextual teaching and learning (ctl) terhadap hasil belajar siswa pada pokok bahasan sistem koloid. Jurnal Pendidikan Kimia, 7(01), 95-101. DOI: 10.24114/jpkim.v7i1.5507

Silaban, S. (2017). Dasar-dasar pendidikan matematika dan ilmu pengetahuan alam. Medan: Harapan Cerdas Publisher.

Silaban, S. (2021). Pengembangan program pengajaran. Medan: Yayasan Kita Menulis.

Sugiyono, P. D. (2017). Metode penelitian bisnis: Pendekatan kuantitatif, kualitatif, kombinasi, dan R\&D. Penerbit CV. Alfabeta: Bandung. 